\title{
At-risk student teachers' attitudes and aspirations as learners and teachers of mathematics
}

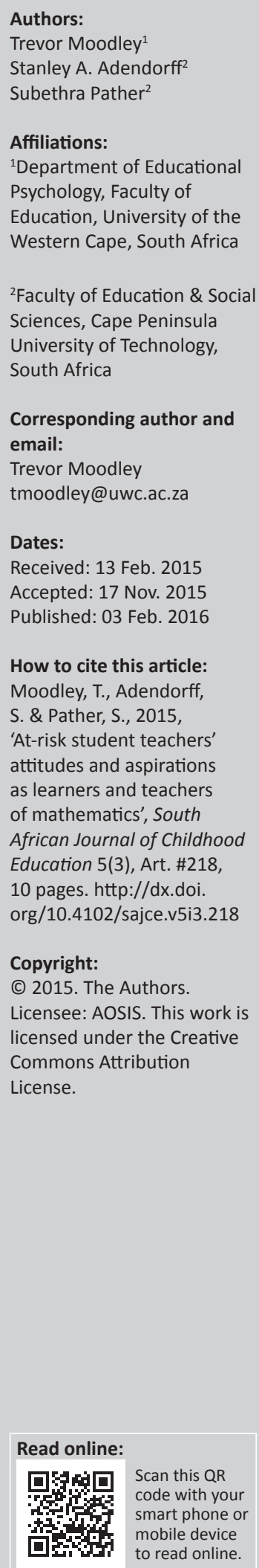

This study explored foundation phase first year student teachers' perceptions about mathematics. The focus on their attitudes towards mathematics in two roles - (1) as learners of mathematics, based on their prior experiences at school and (2) as aspirant teachers of mathematics for children in the early grades. Data sources were students' drawings/collages as well as written interpretations and elaborations of the drawings/collages. The findings indicated that participants had generally negative attitudes towards the learning of mathematics. Factors such as the transition from primary to high school, teacher qualities and mathematics-related anxiety contributed to the shaping of their attitudes. It was encouraging to note that over half the participants expressed positive attitudes in their roles as future teachers, with all expressing the desire to provide better mathematics experiences to their future learners.

\section{Introduction}

The South African Government has expressed concern about acute skills shortages in critical sectors of the South African economy. It has consequently called for greater emphasis on, and investment in, the teaching of mathematics and science at schools and tertiary institutions as a means of responding to these acute skills shortages (Pandor 2008). Hence it is no surprise that the perceived importance of mathematics by the State has prompted the Department of Basic Education to offer mathematics or mathematical literacy as compulsory subjects for the National Senior Certificate (NSC). This has resulted in a shortage of mathematics teachers and learners being forced to either take mathematics or mathematics literacy in Grades 10-12. The perceived importance of success in mathematics emphasised by society produces anxious teachers and learners who form part of a cycle of mathematics anxiety and avoidance (Puteh 2002).

Local and international literature confirms that mathematics anxiety is prevalent among preservice teachers (Hobden \& Mitchell 2011; Mji \& Abayomi 2012). It is therefore important to explore the experiences and beliefs of pre-service teachers since they influence the formation of student attitudes. Teacher attitudes in turn, influence their classroom practices and beliefs (White et al. 2005/2006). Zakaria and Nordin (2008:27) highlight the importance of exploring student teachers attitudes towards mathematics by stating that 'matriculation students may bring these negative feelings to their university studies'.

Teacher education institutions have a major role to play in facilitating change in pre-service teachers' attitudes especially if the aim is to produce mathematics teachers that are competent, confident, socially responsible, and professional. This study addresses this concern by exploring at-risk first-year foundation phase pre-service teachers' attitudes with regard to their past mathematics learning experiences and their aspirations of being a teacher of mathematics. This study provides a unique insight into the participants' mathematics experiences through their own interpretations of their drawings and written reflections which represented their perceptions and attitudes towards mathematics. The following research questions guided this study:

- What past mathematics experiences had an influence on the first-year at-risk Foundation Phase (FP) students' current attitudes towards learning mathematics?

- What were these FP students' attitudes towards their future roles as teachers of mathematics?

\section{Learners and teachers of mathematics}

The key concepts that guided this study are: perceptions of learning and teaching mathematics; students' attitudes toward learning mathematics and mathematics anxiety. The concepts: perceptions, anxiety and attitude are significant to this study and are briefly described below. It is important to note that these concepts have no standardised definitions in meaning. The literature 
offers various definitions as well as differences regarding the relationship that each concept has with the other(s). In addition, there are also differences in the literature regarding the relationship each concept has with other concepts such as thoughts feelings and beliefs.

A perception refers to the action by which the mind refers its sensations to external objects as cause (The Concise Oxford English Dictionary 2006). Schunk and Meece (1992) define student perceptions as thoughts, beliefs and feelings about persons, situations and events. In other studies the term perception is used synonymously with belief (e.g. HoltReynolds 1994; Schoenfeld 1994). Schoenfeld in White et al. (2005/2006:35) 'asserted that mathematical beliefs help constitute a mathematical "world view".

Schunk (1996) argues that pre-service teachers' perceptions about mathematics as well as their mathematics learning and teaching will influence their perceptions of studying mathematics in teacher education institutions which will also be carried with them into their careers as teachers. Studies of students' perceptions of mathematics reveal that their beliefs, attitudes, understanding and experience in learning mathematics are shaped by their long exposure to rulebased instruction at primary and high school (Holt-Reynolds 1994; Schoenfeld 1994; Tchoshanov et al. 2001). Thus, these perceptions have a number of implications, especially to preservice teachers, about what they believe mathematics is and how one should learn and teach mathematics.

A real concern to teacher training institutions is that if preservice teachers graduate from high school with a pessimistic perception of mathematics then this can have serious negative repercussions for the way in which they learn to teach mathematics and their attitude to teaching mathematics once they graduate as teachers.

Educational researchers, specifically in mathematics, have attempted to study student perceptions of learning and learning environments (e.g. Mutodi \& Ngirande 2014; Pather 2012). In order to help pre-service teachers change their negative perceptions and attitudes towards mathematics, it is important that teacher training institutions firstly explore pre-service teachers' perceptions of their prior learning mathematics experiences. Pre-service teachers need to be made aware of their perceptions and within a carefully planned space given the opportunity to address these perceptions of their prior mathematics experiences. This intervention may allow them to shift their perceptions towards a more positive mode. As mentioned earlier, perceptions are intermittently used synonymously with belief, and research about the learning process reveals that students learning mathematics need to believe in their own capacities before making necessary investments in learning strategies that will help them to higher performances (Cobb 1986; Zimmerman 2002).

Research dealing with the impact of the integrated nature of attitude, with specific reference to anxiety (as a form of attitude), and mathematics learning and performance or achievement has quite a long history (Zan \& Di Martino 2007:157). Many researchers use attitude as a term which includes beliefs about mathematics and about one's self or own behaviour (Kapetanas \& Zachariades 2007). Early on Allport (1935) defined attitude as 'a mental and neural state of readiness, organised through experience, exerting a directive and dynamic influence upon the individual's response to all objects and situations with which it is related' (1935:810). Pickens (2005:44) states that 'attitudes are a complex combination of things we tend to call personality, beliefs, values, behavio[u]rs, and motivations'. He further contends that attitudes include a person's feelings, thoughts and behaviours towards people, objects and/or situations. How a person reacts to people, objects and situations will determine their attitude. Hannula (2002) adds that attitude is seen as a category of behaviour that is produced by different evaluative processes. For example, students may express liking or disliking of mathematics because of emotions, expectations or values. Hannula also declares that attitudes can change under appropriate circumstances.

Several studies have revealed that there is an association between teachers' attitudes and their students' attitudes towards mathematics learning and teaching (Anderson 2007; Ma \& Xu 2004). Studies have also been conducted to explore pre-service teachers' prior mathematical experiences and its influence on their attitudes towards learning and teaching mathematics by examining their mathematics autobiographies (Drake 2006; Ellsworth \& Buss 2000; Hobden \& Mitchell 2011). Ellsworth and Buss (2000) explored preservice teachers' prior mathematics experiences at school. That study revealed that participants' school teachers had a very influential effect, be it positive or negative, on their attitudes towards mathematics. However, Jong and Hodges (2013) suggest that regardless of the nature of pre-service teachers' prior experiences in mathematics, it is possible for mathematics education lecturers to change pre-service teachers' attitudes and confidence to teach mathematics by providing meaningful mathematics experiences in methods courses, supportive field experiences, and continued professional development.

This study hoped to provide the first step towards meaningful experiences of mathematics in the B.Ed. Foundation Phase undergraduate course by making students reflect on their prior mathematics experiences and their perceptions of teaching mathematics. It is envisaged that this study followed by appropriate support at university, will encourage a positive shift of students' perceptions and attitudes to learning and teaching mathematics.

\section{Learner anxiety}

Research indicates that students' attitude towards mathematics is closely related to the degree of anxiety that students experience and the attitudes they might hold of mathematics (Hembree 1992; Mullis et al. 2001). In this regard 
'some research suggests[s] that students with negative attitudes toward mathematics have performance problems simply because of anxiety' (Tapia \& Marsh 2004:1).

Anxiety has been found to be one of the most prevalent emotional problems associated with mathematics learning (Baloğlu \& Koçak 2005). Cates and Rhymer (2003:23) offer the following description of mathematics anxiety: 'a condition in which students experience negative reactions to mathematical concepts ... and evaluation procedures ...' without actually saying whether the condition is psychological, affective, or cognitive. In contrast Uusimaki and Nason (2004:369) stress the fact that mathematics anxiety 'is not a discrete condition'. The most commonly used definition, which is also appropriate to this study, describes mathematics anxiety as 'feelings of tension and anxiety that interfere with the manipulations of mathematical problems in a wide variety of ordinary life and academic situations' (Richardson \& Suinn 1972:551).

In recent years there has been many studies documenting pre-service teachers' mathematics anxiety (e.g. Peker 2009; Rayner, Pitsolantis \& Osana 2009; Uusimaki \& Nason 2004). A number of factors have been associated with mathematics anxiety ranging from home environment factors such as family pressure for higher achievement; to intellectual factors such as learning styles; or dispositional factors which are internal and related to personality such as low selfesteem or situational factors (e.g. classroom climate) which are external immediate factors surrounding the stimulus (Baloğlu \& Koçak 2005; Yüksel-Şahin 2008). Peker (2009) offered the following reasons as to why pre-service teachers' mathematics teaching anxiety may arise: if the mathematics being taught is too difficult: mathematics knowledge of the pre-service teacher is inadequate: the level of interest towards the teaching profession may be lacking: the inability to teach to the appropriate level of the learners/grade; and learning style preferences may affect the pre-service teachers' mathematics teaching anxiety.

According to Uusimaki and Nason (2004) most of the preservice teachers' mathematics anxiety could be attributed to situational factors. For example the majority of the participants in their study revealed that their mathematics anxiety could be attributed to their primary school mathematics learning experiences. They were able to remember the exact year in their primary school experience in which they learnt to dislike mathematics. The perceived reason accredited was that of the teacher rather than the mathematical content or social factors. The study identified three other situational factors related to the mathematics anxiety experienced by the pre-service teachers. The first situational factor related to mathematics anxiety, was experienced when they had to communicate their knowledge of mathematics either in a test situation or verbal explanation. The second cause of anxiety cited by Uusimaki and Nason (2004) was the teaching of mathematics by the pre-service teachers in a practice teaching situation. Anxiety levels were high due to an increased feeling of making mistakes whilst teaching mathematics or not being able to solve the mathematical problem correctly. Lastly many of the pre-service teachers felt anxious about the mathematics content knowledge, the strand of the mathematics syllabus that caused most anxiety were algebra and patterns, space and number sense.

The relationship between mathematics anxiety and mathematics content knowledge is also evident in Rayner et al.'s (2009) study. Their study not only added to the existing body of knowledge about the relationship between mathematics anxiety and mathematics content knowledge; their study may be the first to directly examine the role of mathematics understanding in pre-service teachers' mathematics anxiety.

Dealing with issues relating to pre-service at-risk students' attitude towards learning and teaching mathematics and mathematics anxiety in this study was seen as an important contribution to the knowledge in this area. More specifically the use of drawings to explore students' perceptions of their prior mathematics experiences and their perceptions as future teachers of teaching mathematics has contributed to the uniqueness of the study.

\section{Signposts for the study}

The research questions and the literature reviewed provided guidance in the construction of the conceptual framework used in this study. The concepts described below provide a set of general signposts that guided this study. In this study the term perceptions is considered to be an umbrella (comprehensive) concept under which attitude resorts, that is, the way students perceive mathematics ultimately shapes their attitudes. Perception is thus viewed as 'closely related to attitudes' (Pickens 2005:52). The emphasis is on a 'tridimensional' (Di Martino 2010; Hart 1989; Pepin 2011) description of attitude which identifies three interrelated aspects that form the essential components of attitudes, namely:

- the degree of affect (the emotional) associated with mathematics

- the beliefs regarding mathematics; and finally

- the behaviour related to mathematics.

Affective points towards how students think and feel about mathematics. Pepin (2011:537) refers to it as 'emotional disposition towards mathematics expressed with phrases such as 'Ilike/dislike mathematics'. Beliefs about mathematics point towards remarks, such as 'I will never be good at mathematics'; and 'Not everybody can do mathematics'. A student's beliefs can influence how a problem is approached, what avoidance strategies are employed as well as the time spent on tasks, and the degree of intensity of work (Marchis 2011:787; Schoenfeld 1985:45). Behaviour is related to how learners respond to certain situations involving mathematics, such as becoming anxious, nervous, inability to think straight, avoiding homework and bunking class. 


\section{Methods}

This study was conducted within an interpretive paradigm which acknowledges the subjective meaning (De Vos et al. 2011) that students attributed to their learning of mathematics and to their aspirations as future teachers of mathematics. The participants were selected purposively at the beginning of the academic year from a total population of 120 first year BEd. students registered at a university of technology. Students who had failed the mathematics baseline test administered by the faculty at the commencement of the academic year, were regarded as mathematically at-'risk'. These students $(n=43)$ were advised to attend the mathematics intervention programme aimed at supporting at-risk students. The programme included remedial and tutorial classes. All the students in the intervention class were invited to be part of the study. After permission was granted by the university to conduct the study, participants were informed about the study aims and outcomes, as well as their rights including: voluntary participation and withdrawal at any time, anonymity, confidentiality and access to counselling support services on request. All the at-risk students gave their written consent to participate prior to the study commencing.

\section{Data collection and analysis}

As an integral part of the interpretivist approach to this inquiry, two data collection methods were employed: students' drawings and their written reflections. The decision to use different media: visual imagery (drawings/collages) as well as written descriptions of participant perceptions was based on the view that the drawings would provide additional perspectives into what and how participants felt. Similar to Zan and Di Martino (2007:157) the intention was to move beyond 'the normative that characterises most research on attitude ...' and to adopt 'an interpretive approach, investigating students' relationship with mathematics "from the bottom" and trying to spot in their descriptions the dimensions involved' (Zan \& Di Martino 2007:162). The two activities chosen for data collection ensured a deeper understanding of the students' prior perceptions and future aspirations of teaching and learning mathematics. The drawings/collage allowed us, the researchers, a more in-depth and less linear view into a complex reallife situation of the students. According to Caldwell and Moore (1991) the use of drawing images or sketches compared to writing or verbalising ideas can facilitate in generating more creative responses and ideas. In instances when participants are second or third language speakers (as was the case among some of the participants in this study), limitations may exist in them expressing themselves adequately if restricted to providing only written responses (Burton 2009).

The writing brought further clarity and expression to their view on learning and teaching mathematics. In addition the data collection activities allowed for triangulation. Table 1 provides a description of the two specific tasks that were
TABLE 1: Task instructions to illustrate participants' perceptions and experiences of learning and teaching mathematics.

\begin{tabular}{lll}
\hline Tasks & Description & Completion \\
\hline 1 & $\begin{array}{l}\text { Participants were required to provide a visual } \\
\text { (drawing/collage) of their prior learning experiences } \\
\text { of mathematics. In addition a written activity was } \\
\text { also required to accompany their drawings which } \\
\text { provided their interpretation of the drawing and } \\
\text { opinions and perceptions of their mathematics } \\
\text { learning and learning environment at school. }\end{array}$ & $\begin{array}{l}\text { First week } \\
\text { of academic } \\
\text { year }\end{array}$ \\
2 & $\begin{array}{l}\text { Participants were once again required to follow } \\
\text { the same activity as task 1 but this time the focus } \\
\text { was on their aspirations of being a teacher of } \\
\text { mathematics. Their drawings and written activity } \\
\text { needed to reflect their perceptions and expectations } \\
\text { of teaching mathematics. }\end{array}$ & End of first \\
\end{tabular}

given to the at-risk mathematics first-year students in the intervention class. The first task was completed shortly after students consented to participate in the study. The second task was completed towards the end of the academic year, after participants had attended mathematics tutorial classes for the year. The reasoning was that a period of intervention may have had a positive effect on these at-risk students' attitudes towards mathematics, especially in their roles as future teachers of the subject. Participants would also have had some teaching practice experience.

The dual activity elicited the participants' perceptions as learners and teachers of mathematics. A constant comparative analysis (Strauss \& Corbin 2008) was used to analyse the drawings and written reflections in task 1 and 2 independently. Constant comparison analysis refers to the process whereby data is placed in initial categories and then by constantly comparing the data to each other, broader related categories are developed. Three initial pre-selected categories were determined by using an emergent analytical coding process (see Table 2).

By using the initial categories from Table 2 and constantly comparing the data from the drawings with the written responses ensured that the emergent categories accurately reflected and included the data from which the categories were established. The drawings were analysed by examining the actual objects drawn and the attitudinal conceptions expressed in the drawings. The constant comparison analysis took place simultaneously with the participants' written responses. All three researchers were involved in this process. Categories from the drawings and the written responses were merged to form broader categories relating to students learning and teaching of mathematics which are discussed in the results section.

TABLE 2: Pre-selected categories.

\begin{tabular}{lll}
\hline Categories & $\begin{array}{l}\text { Task 1- prior } \\
\text { experiences as a } \\
\text { learner }\end{array}$ & $\begin{array}{l}\text { Task 2- aspirations as } \\
\text { a future mathematics } \\
\text { teacher }\end{array}$ \\
\hline $\begin{array}{l}\text { 1. Attitudes: positive, } \\
\text { negative and/or neutral }\end{array}$ & $\begin{array}{l}\text { Affects, beliefs, } \\
\text { behaviours }\end{array}$ & $\begin{array}{l}\text { Affects, beliefs, } \\
\text { behaviours }\end{array}$ \\
$\begin{array}{l}\text { 2. Teacher influences } \\
\text { Experiences of } \\
\text { teachers at school }\end{array}$ & $\begin{array}{l}\text { Teaching styles } \\
\text { contemplated }\end{array}$ \\
$\begin{array}{l}\text { 3. Other experiences/ } \\
\text { features }\end{array}$ & $\begin{array}{l}\text { Classroom } \\
\text { environment; phase } \\
\text { of schooling, external } \\
\text { influences }\end{array}$ & $\begin{array}{l}\text { Classroom } \\
\text { environment; external } \\
\text { influences; curriculum } \\
\text { factors }\end{array}$ \\
\hline
\end{tabular}

Note: Attitude shifts in roles as learners of mathematics to being aspirant teachers of mathematics in the Foundation Phase. 


\section{Analysis of respondents' written descriptions}

Participants' written descriptions, namely: as learners as well as teachers of mathematics were analysed for a second time after the categorisation of the two sets of drawing/collages. Their written descriptions as learners of mathematics were initially analysed independently from their written narratives as aspiring teachers of mathematics. Content analysis was used to analyse the data of the two sets of written narratives. Next, each participant's set of written narratives were analysed together to gain a deeper understanding of the possible role their experiences as learners of mathematics play in their perceptions of themselves as aspiring teachers of mathematics.

The analysis of both the drawings/collages and the written descriptions revealed different themes relating to participants' perceptions about their experiences as learners of mathematics and their views as aspiring teachers of mathematics in formal settings.

\section{Ethics considerations}

Ethical consideration was granted by the University of the Western Cape (South Africa), EFEC 6-5/2012.

\section{Findings and discussion}

The analyses of data are reported in terms of participants' attitudes as learners of mathematics, factors that had an impact on their experiences as learners of mathematics and their attitudes as aspirant teachers of mathematics in the FP.

\section{Participants' perceptions as learners of mathematics}

Participants' attitudes as learners of mathematics were categorised in terms of Pepin's (2011) conceptualisation of attitude as constituting the affective, belief and behaviour domains. The affective domain of participants' attitudes was evident in terms of comments such as: 'Math was scary'; 'I hated math'; 'Very anxious' and 'I loved math'. The belief domain of participants' attitudes was represented by reflections including: 'I was not smart enough'; 'I simply could not just understand it' and 'Primary school math was a pleasure'. The behaviour domain of participants' attitudes was represented by expressions such as: 'I struggled with math' and 'Avoid embarrassment as much as possible'. Figure 1 illustrates the variation in responses which were also categorised in terms of three attitude indicators, namely: positive, both positive and negative and negative. Table 3 provides as a quantitative breakdown of participants' attitudes related to their prior experiences as learners of mathematics.

TABLE 3: Categorisation of participants based on their responses to their prior learning of mathematics.

\begin{tabular}{lc}
\hline Categories & $\mathbf{\%}$ \\
\hline Overwhelmingly negative & 30 \\
Very negative with a few positive remarks & 18.5 \\
Positive and negative remarks more or less equal & 37 \\
More positive descriptions with very few negative comments & 11 \\
Positive comments with no negative remarks & 3.5 \\
\hline
\end{tabular}

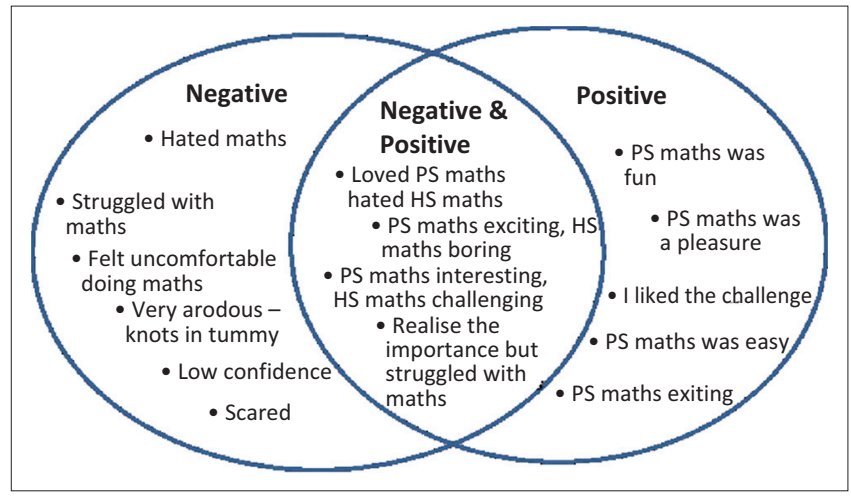

Source: Compiled by authors of this study.

FIGURE 1: Participants' attitudes towards the learning of mathematics.

\section{Categorisation of participants based on their responses on the positive-negative attitude continuum}

Participants were also categorised in terms of their responses varying from overwhelmingly negative to positive remarks which is illustrated in Table 3. Table 3 indicates that $30 \%$ of the participants indicated overwhelmingly negative attitudes towards the learning of mathematics. Some participants $(18.5 \%)$ made very negative remarks, but included a few positive remarks. Over a third of the participants (37\%) had positive and negative remarks that were equally represented. A small number of participants $(11 \%)$ made more positive remarks with very few negative remarks whilst a negligible number of participants (3.5\%) made only positive remarks about their experiences as learners of mathematics. The variation in responses represent the complex nature of exploring attitudes (Pickens 2005) that are formed by different evaluative processes (Hannula 2002).

\section{Participants' mathematics experiences in transition from primary to high school}

Whilst a few participants (12\%) reported feelings of negativity from the onset of formal schooling, the majority of the participants reported that the initial years of formal mathematics learning was satisfactory until they had reached high school (grades eight and nine). The transition from primary to high school seemed to be a major contributor to the development of overwhelmingly negative attitudes towards the learning of mathematics. Most of the participants (70\%) that had an equal number of positive and negative responses, recall positive experiences about mathematics in primary school (PS) and negative experiences once they reached high school (HS). Many of these responses (85\%) reflected the difficulty experienced in understanding HS mathematics. These findings are supported by Borthwick (2011:37) who states that 'among the reasons attributed to the crisis in mathematics education, disaffection with [high school learners] remains high'. The following participant responses illustrate the challenges learners face in learning mathematics once entering high school:

Primary school (PS) maths was fun because my teacher made it interesting and exciting; 'I felt uncomfortable doing maths because it was compulsory and I was forced to do it'; 'I realised 
the importance of maths at HS but struggled with the content ...... it was very challenging and difficult', 'I loved PS maths .... I was proud of myself .... my marks were really good. HS my feelings towards maths changes .... I was anxious, it was challenging ...... it made me sad'.

\section{Participants experiences of their mathematics teachers during their years at school}

Almost half the participants' $(47 \%)$ attitudes related to their experiences of their mathematics teachers. Midgley, Feldlaufer and Eccles (1989:988) maintain that the 'value of math increases for [learners] who move from less supportive to more supportive teachers'. Participants' responses included teacher attitudes towards learners and their ability to teach the subject. Dowker, Ashcraft and Krinzinger (2012:2) reported 'a strong relationship between ... negative perceptions of teaching and experiencing negative attitudes toward mathematics'. There is an association between teachers' attitudes and those of their students towards mathematics (Anderson 2007; Ma \& Xu 2004).

\section{Some positive and negative comments about teachers were:}

'Amazing teacher'; 'He taught with passion'; 'Teachers explained work properly'; 'Teacher used fear to bring his knowledge across'; 'Grade 8-9 teacher was horrible - scared to ask her questions made me feel dumb. Grade 10-11 teacher explained too fast'; 'HS teacher was not good, although did explain I still didn't understand'; 'Teacher had favourites [learners who did well at math]'; 'The lessons was teacher centred, he asked lots of questions, ... wasn't good'; 'Attention was given to the top learners'.

\section{Mathematics anxiety and negative attitudes towards the learning of mathematics}

As previously mentioned, research has found an association between attitude towards learning mathematics and mathematics anxiety (Hembree 1992; Mullis et al. 2001). In fact, Ma and Kishor (1997) consider mathematics anxiety to be one dimension of attitude towards mathematics. Jennison and Beswick's study (2010) furthermore highlight the interrelationships among learner understanding, learner attitude and mathematics anxiety. They also emphasise the roles of both cognitive and affective aspects of learning and teaching mathematics. In the current study, many of the participant responses $(79 \%)$ suggested the interrelatedness between anxiety and attitude in relation to the learning of mathematics.

The following excerpts represent the anxiety participants experienced when engaging with mathematics at school:

'Nervous when marks were reported in classroom'; 'prayed that I was not asked to solve a problem on the board'; 'having different teachers throughout the year was not nice'; 'I had to stand in front of the class with everyone's eye focused on you they think and wonder whether you would get the sum right or not'. 'Biggest fear to write a math test I started getting nervous, my whole body would sweat, anxiety would build up inside me. I would have a very painful headache'.

Two participants' 'products' are analysed below to provide an authentic glimpse into the rich data that was collected. Figure 2 and Figure 3 provide a sample of the picture/ collage and accompanying written narrations of individual participants' experiences as learners of mathematics. These figures demonstrate the congruency of the message represented in both the graphical and written representations of each participant.

Student A in Figure 2 drew herself expressing anxiety (the big eyes), fear (the concave mouth), desperation (tears flowing), confusion (questions marks around the face), feeling of hopelessness (iced heart that cracked under pressure), and utter lack of confidence (being taunted by laughing numbers) are quite intense and alarming. The accompanying narrative (Figure 2) clearly demonstrates the situational

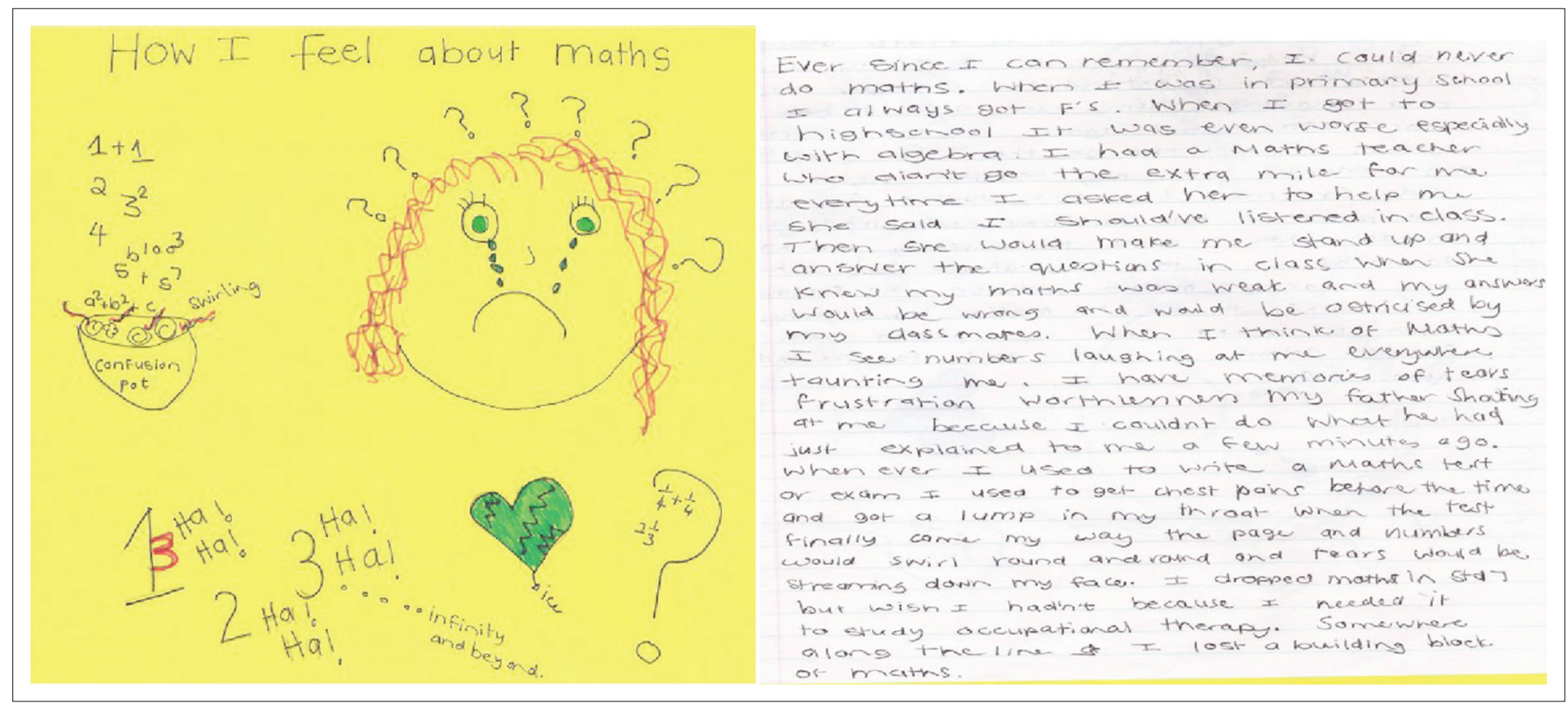

Source: The methodology of the study included participants doing drawings anonymously as part of the data collection so this drawing is a finding of the research.

FIGURE 2: Student A. 


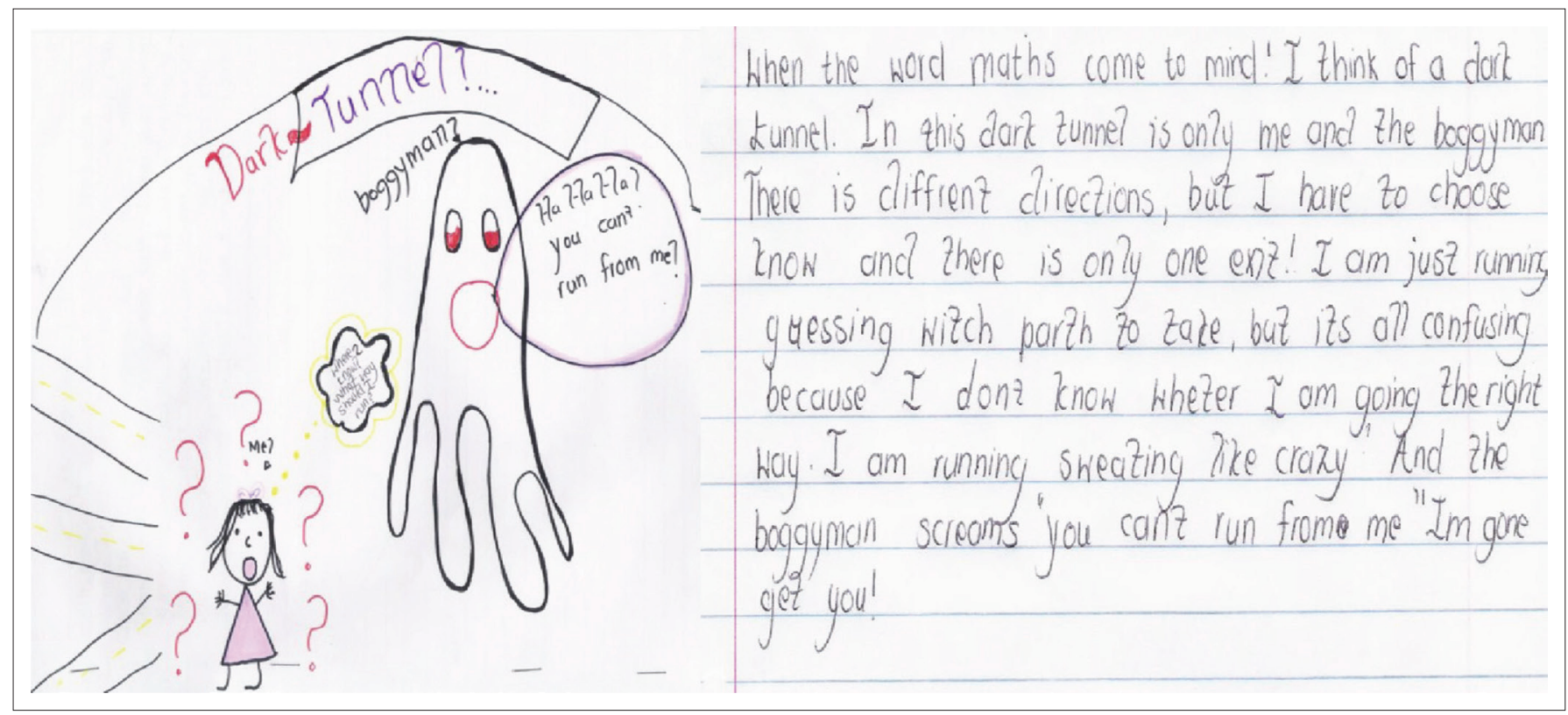

Source: The methodology of the study included participants doing drawings anonymously as part of the data collection so this drawing is a finding of the research.

FIGURE 3: Student B

factors (teacher and father), embarrassment and regret at dropping mathematics in high school. The anxiety theme is repeated by participant B in Figure 3 with the bogeyman metaphor used to represent the learning of mathematics. The accompanying narrative (Figure 3 ) describes the terror and hopelessness experienced in learning mathematics as well as the learner's attempt to escape from 'mathematics' as also mentioned by Puteh (2002). Figure 2 and Figure 3 indicate a number of situational factors that contributed to the portrayed anxiety participants felt in their prior learning experiences of mathematics (Uusimaki \& Nason 2004). They also demonstrate Martinez and Martinez (1996) claim that mathematics anxiety has multiple causes and multiple effects. Both sets of figures also suggest the negative impact of the mathematics anxiety on the participants' self-esteem. Participant A (Figure 2) states: 'I have memories of tears frustrations worthlessness' and the large monster towering over the small sketch representation of participant B (Figure 3) are clear indicators of low self-esteem. According to Cemen (1987) mathematics anxiety is a perceived threat to self-esteem.

\section{Participants' perceptions as aspirant teachers of mathematics}

Pre-service mathematics teachers' beliefs or feelings about mathematics may hold serious implications for the academic progress of their future learners. This statement links with research conducted by Uusimaki and Nason (2004) as well as Charalambous, Philippou and Kyriakides (2002), who emphasise the fact that teachers' beliefs and feelings concerning mathematics 'have a powerful impact on the practice of teaching' (Uusimaki \& Nason 2004:369). Findings related to participants' aspirations as future teachers will now be discussed.

\section{Categorisation of participants' attitudes on the positive-negative continuum}

Participants' drawings/collages and written reflections revealed their attitudes about being future teachers of mathematics. Table 4 lists the frequency of terms that participants used to express their attitudes in relation to their roles as future Foundation Phase teachers teaching mathematics.

Table 4 illustrates the categorisation of participants' attitudes as aspirant teachers of mathematics in the Foundation Phase. The categorisation indicated that just less than half $(47 \%)$ of the students had positive attitudes, about a third (31\%) expressed negative attitudes and the remaining students $(22 \%)$ expressed both positive and negative attitudes in relation to their future roles as mathematics teachers in the Foundation Phase. The variation in responses may be due to

TABLE 4: Participants' attitudes in relation to their roles as future mathematics teachers in the Foundation Phase.

\begin{tabular}{|c|c|c|}
\hline Positive attitudes (47\%) & Negative attitudes $(31 \%)$ & Both positive and negative attitudes $(22 \%)$ \\
\hline Happy & Nervous & Nervous/afraid/excited \\
\hline Excited & Scared & Nervous/scared/not \\
\hline Confident Enjoy & Fear of failing & confident \\
\hline Want to be confident & Don't like maths Fear & Happy/excited/bit scared \\
\hline Pride \& rewarding positive will try as a teacher & $\begin{array}{l}\text { Worried Hands sweaty/very nervous/don't know what type of } \\
\text { teacher I am going to be }\end{array}$ & Scared but excited/concerned \\
\hline Will make teaching and learning much better & - & Scared but will teach \\
\hline
\end{tabular}


a number of factors including the complex nature of attitudes (Pickens 2005).

\section{Categorisation of participants' attitudes as aspirant mathematic teachers}

Participants' attitudes towards teaching mathematics are expressed in terms of how they felt (the affective), their beliefs, and their behaviour using Pepin's conceptualisation of attitudes (Pepin 2011). Firstly, the affective dimension that defines attitude points towards how students think and feel about mathematics. Table 4 indicates that there were a range of emotions expressed by students; both in terms of diversity (e.g. happy, scared, fear, don't like maths, positive) and intensity (e.g. confident, ... happy, ... excited). Pepin (2011:537) refers to it as 'emotional disposition towards mathematics expressed with phrases such as "I like/dislike mathematics"'. Similarly, respondents in this study used phrases such as the following:

'scared to teach wrong methods'; 'lack(s) confidence because of'; 'want to feel confident in subject'; 'scared that fear of mathematics will affect teaching'; and 'concerned - wants to be ok in mathematics'.

Secondly, participants' beliefs about mathematics point towards remarks, such as 'I will never be good at mathematics'; and 'not everybody can do mathematics'. As previously mentioned, a student's beliefs can influence how a problem is approached, what avoidance strategies are employed as well as the time spent on tasks, and the degree of intensity of work (Marchis 2011:787; Schoenfeld 1985:45). Similarly, in this study participants' beliefs about being a mathematics teacher were linked to approach, and avoidance strategies as reflected in the following comments:

'The teacher should be helpful, confident even in tough times'; 'It's up to me to make the learners enjoy mathematics'; 'I am not confident, and scared of teaching wrong mathematics to learners'; 'I want to be the best mathematics teacher'; 'Although lack of understanding is a problem, I am hopeful of future'.

Some students displayed a mature attitude in their beliefs about teaching mathematics despite having had negative experiences relating to mathematics and a consequent fear of teaching mathematics. Their maturity was demonstrated by reframing their negative experiences in light of their responsibilities as future mathematics teachers. In effect, some respondents expressed a will to overcome their negative disposition towards math as demonstrated by the following quote: 'I will overcome it'; 'I will win, it's about the child, their needs and what is best for them'; 'I am looking with new eyes and a positive self-image'.

The third domain of attitude, namely behaviour related to students' responses in certain mathematics situations, such as becoming anxious, nervous, inability to think straight, avoiding homework and bunking class (Pepin 2011). Participants' responses in this study elaborated on their beliefs by reporting on intended actions. The participants' comments thus relate to their intended actions in the mathematics classroom situation, such as: 'I want to change learners' attitudes - to make it exciting'; 'I will go for additional courses and encourage learners'; 'I will treat learners as equal $[y]^{\prime}$.

\section{Participant responses in their future roles as teachers of mathematics and the mathematics curriculum}

Some participants' (23\%) responses focussed on the mathematics curriculum. Three discrete distinctions related to teaching mathematics were identified when respondents commented about the mathematics curriculum. The following categories were identified: (1) some understood curriculum to be consisting of pedagogical content knowledge (PCK) by referring to specific content knowledge (Ball, Thames \& Phelps 2008:389-390) such as basic numeracy skills and mathematics involving problem-solving; (2) Others remarked from a teaching perspective, by referring to procedural knowledge and pacing of mathematics content, and (3) others spoke about the value of the curriculum - to become a productive citizen and apply mathematics knowledge to everyday life situations.

\section{Participant responses regarding their anticipated teaching styles}

Participants also referred to teaching styles as future mathematics teachers. Their descriptions of the teaching styles they hoped to adopt centred essentially around two points of view, namely the teaching methods and techniques they would employ, and the affective and social dimensions to make learning mathematics a pleasant educational experience. For example:

I will work hard, slowly and step by step to turn it into positivity; the negative wall I shall break that's preventing me from touching and sharing that positive space.

This quotation depicts the general trend of what the respondents hoped to achieve as future mathematics teachers.

The teaching techniques mentioned focussed on the use of 'physical activities', making learning interactive by using 'small group activities'. Significant is the idea of creating and grasping 'learning moments [created] through learners' mistakes', and creating an atmosphere that would elicit 'questions from learners'. This is viewed as an essential element of classroom communication. In addition to group work, the position of the individual is deemed crucial. Getting learners to eventually operate on the same cognitive level is viewed as priority by 'breaking down content', making it accessible, and 'making mathematics real' by making learners 'feel comfortable'. There were those respondents who emphasised the role of procedural techniques, by highlighting 'step by step procedures' and slow teaching pace to accommodate all learners. The affective domain as it relates to respondents' belief-systems is clearly visible in the way they anticipated how their future mathematics classroom would 
be constituted to enhance and optimise learning, namely: to make it fun, and interesting and to ensure understanding; incorporating 'positive new ideas' into the classroom; to literally 'nurture' learners to develop positive attitudes toward mathematics students. Feeling comfortable so as to not to be afraid to make mistakes, but experiencing it as fun and exciting are stated as crucial to enhance learning and to develop an affinity for mathematics. In addition words such as 'motivation' and 'encouragement' further highlight the desire to create a learning atmosphere that may be in contrast to their own experiences when they were learners. It was encouraging to note that all the participants expressed a genuine desire to provide children with better mathematics learning experiences than their own even though there were some reservations expressed by some participants such as fears in terms of mathematics content knowledge and low confidence. Many of the responses related to both the affective and cognitive components in the learning and teaching of mathematics (Jennison \& Beswick 2010), thus emphasising the importance of holistic teaching.

\section{Shifts in participants' attitudes in their roles as learners vs. aspirant teachers of mathematics}

A comparative analysis was also done to gauge if there were any shifts in participants' attitudes in their different roles as: (1) as learners of mathematics and (2) as aspirant teachers of the subject in the Foundation Phase (Table 5). This was as an attempt at gauging their mathematical 'world view' in their different roles which according to Schoenfeld (1994) is constituted by a person's mathematical beliefs.

The analysis revealed that $11 \%$ of the participants expressed positive attitudes whilst $24 \%$ expressed negative attitudes in both roles. Anegligible number of participants (3\%) expressed positive attitudes as learners but not as future teachers of mathematics, whilst $18 \%$ of the participants expressed negative attitudes as learners but positive attitudes as future mathematics teachers.

There were also mixed (both positive and negative) attitudes expressed by some participants (14\%) in both roles as learners and future teachers of mathematics. About $24 \%$ of the participants initially expressed mixed attitudes in their roles as learners but expressed positive attitudes as future teachers. A few participants $(6 \%)$ had expressed initial negative attitudes as learners but 'progressed' to a mixed report of

TABLE 5: Comparative analyses of participants' attitudes as learners vs. teachers of mathematics. (Attitude shifts in roles as learners of mathematics to being aspirant teachers of mathematics in the Foundation Phase)

\begin{tabular}{lll}
\hline Learner & Aspirant Teacher & $\begin{array}{l}\text { \% age of } \\
\text { participants }\end{array}$ \\
\hline Positive & Positive & 11 \\
Positive & Negative & 3 \\
Negative & Negative & 24 \\
Negative & Positive & 18 \\
Both positive and negative & Both positive and negative & 14 \\
Both positive and negative & Positive & 24 \\
Both positive and negative & Negative & 6 \\
\hline
\end{tabular}

attitudes as future teachers. Overall, just over half of the participants (53\%) and less than one-third (27\%) respectively expressed positive and negative attitudes as future teachers. The apparent shifts in the attitudes of some participants are partially supported by Hannula (2002) who contends that attitudes can change under appropriate circumstances and that regardless of their nature; prior mathematics experiences can be useful in moulding student teachers attitudes to provide meaningful mathematics experiences for their future learners (Jong \& Hodges 2013).

\section{Conclusion}

This study explored FP first year at-risk student teachers' attitudes about the mathematics in terms of their past experiences as learners and their future roles as teachers. The study highlighted the different factors that played a role in shaping their attitudes towards mathematics as learners. Most of the responses indicated a negative disposition towards mathematics and indications of students experiencing anxiety about mathematics. The findings are encouraging because the student teachers expressed a desire to provide meaningful mathematics learning experiences in their future roles as teachers; despite their own largely negative experiences of mathematics. The uniqueness of the study is the approach used to collect data. Participants did drawings/collages and then provided their own written and interpretations and elaborations of the drawings to represent their perceptions of mathematics as both learners and aspirant teachers.

\section{Competing interests}

The authors declare that they have no financial or personal relationships which may have inappropriately influenced them in writing this article.

\section{Authors' contributions}

T.M. (University of the Western Cape), S.A. (Cape Peninsula University of Technology) and S.P. (Cape Peninsula University of Technology) contributed equally to the writing of this article.

\section{References}

Allport, G.W., 1935, 'Attitudes', in C. Murchison (ed.), Handbook of social psychology, pp. 798-844, Clark University Press, Worcester.

Anderson, R., 2007, 'Being a mathematics learner: Four faces of identity', The Mathematics Educator 17, 7-14.

Ball, D., Thames, M.H. \& Phelps, G., 2008, 'Content knowledge for teaching. What makes it special?', Journal of Teacher Education 59(5), 389-405.

Baloğlu, M. \& Ko?lak, R., 2005, 'A multivariate investigation of the differences in mathematics anxiety', Personality and Individual Differences 40, 1325-1335.

Borthwick, A., 2011, 'Children's perceptions of, and attitudes towards, their mathematics lessons', in C. Smith (ed.), Proceedings of the British Society for research into learning mathematics, 31 , pp. 37-42, London.

Burton, M., 2009, 'Exploring the changing perception of mathematics among elementary teacher candidates through drawings', in S.L. Swars, D.W. Stinson $\&$ S. Lemons-Smith (eds.), Proceedings of the 31st annual meeting of the North American Chapter of the International Group for the Psychology of Mathematics Education, Georgia State University, Atlanta.

Caldwell, H. \& Moore, B.H., 1991, 'The art of writing: Drawing as preparation for narrative writing in the primary grades', Studies in Art Education: A Journal of Issues and Research 32(4), 207-219. 
Cates, G.L. \& Rhymer, K.N., 2003, 'Examining the relationship between mathematics anxiety and mathematics performance: An instructional hierarchy perspective', anxiety and mathematics performance: An in
Journal of Behavioral Education 12, 23-34.

Cemen, P.B., 1987, The nature of mathematics anxiety, Report No. SE 048689 , Oklahoma State University, Stillwater, OK. (ERIC Document Reproduction Service No. ED287729.)

Charalambous, C., Philippou, G. \& Kyriakides, L., 2002, 'Towards understanding teachers' philosophical beliefs about mathematics', paper presented at the 26th Annual Conference of the International Group for the Psychology of Mathematics Education, Norwich, England.

Cobb, P., 1986, 'Contexts, goals, beliefs and learning mathematics', For the Learning of Mathematics 6(2), 2-9.

De Vos, A.S., Strydom, H., Fouché, C.B. \& Delport, C.S.L., 2011, Research at grass roots: For the social sciences and human service professions, 4th edn., Van Schaik Publishers, Pretoria.

Di Martino, P., 2010, “Maths and me": Software analysis of narrative data about attitude towards math', Proceedings of CERME 6, Lyon, France, January 28thFebruary 1st, 2009.

Dowker, A., Ashcraft, M. \& Krinzinger, H., 2012, 'The development of attitudes and emotions related to mathematics', Child Development Research 2012, Article ID 238435, 3 pages.

Drake, C., 2006, 'Turning points: Using teachers' mathematics life stories to understand the implementation of mathematics education reform', Journal of Mathematics the implementation of mathematics
Teacher Education 9(6), 579-608.

Ellsworth, J.Z. \& Buss, A., 2000, 'Autobiographical stories from pre-service elementary mathematics and science students: Implications for K-16 teaching', School Science and Mathematics 100(7), 355-364.

Hannula, M.S., 2002, 'Attitude towards mathematics: Emotions, expectations and values', Educational Studies in Mathematics 49(1), 25-46.

Hart, L., 1989, 'Describing the affective domain: Saying what we mean', in D. McLeod $\&$ V. Adams (eds.), Affect and mathematical problem solving, pp. 37-45, Springe Verlag, New York.

Hembree, R., 1992, 'Experiments and relational studies in problem solving: A metaanalysis', Journal for Research in Mathematics Education 23(3), 242-273.

Hobden, S. \& Mitchell, C., 2011, 'Maths and me: Using mathematics autobiographies to gain insight into the breakdown of mathematics learning', Education as Change 15(1), 33-46.

Holt-Reynolds, D., 1994, 'Learning teaching, teaching teachers', paper presented at the American' Educational Research Association, New Orleans, LA.

Jennison, M. \& Beswick, K., 2010, 'Student attitude, student understanding and mathematics', in L. Sparrow, B. Kissane \& C. Hurst (eds.), Shaping the future of mathematics education: Proceedings of the 33rd Annual Conference of the Mathematics Education Research Group of Australasia, MERGA, Fremantle.

Jong, C. \& Hodges, T.E., 2013, 'The influence of elementary pre-service teachers' mathematical experiences on their attitudes towards teaching and learning mathematics', International Electronic Journal of Mathematics Education 8(2-3), 100-122.

Kapetanas, E. \& Zachariades, T., 2007, 'Students' beliefs and attitudes about studying and learning mathematics', in J.H. Woo, H.C. Lew, K.S. Park \& D.Y. Seo (eds.), Proceedings of the 31st Conference of the International Group for the Psychology of Mathematics Education, Vol. 3, pp. 97-104, PME, Seoul.

Ma, X. \& Kishor, N., 1997, 'Assessing the relationship between attitude toward mathematics and achievement in mathematics: A meta-analysis', Journal for Research in Mathematics Education 28(1), 26-47.

Ma, X. \& Xu, J., 2004, 'The causal ordering of mathematics anxiety and mathematics achievement: A longitudinal panel analysis', Journal of Adolescence 27(2), 165179.

Marchis, I., 2011, 'Factors that influence secondary school students' attitude to mathematics', Procedia - Social and Behavioral Sciences 29, 786-793.

Martinez, J.G.R. \& Martinez, N.C., 1996, Math without fear, Allyn and Bacon, Needham Heights.

Midgley, C., Feldlaufer, H. \& Eccles, J., 1989, 'Student/teacher relations and attitudes toward mathematics before and after the transition to junior high school', Child toward mathematics before
Development 60, 981-992.

Mji, A. \& Abayomi, A., 2012, 'Relationships between and among pre-service mathematics teachers' conceptions, efficacy, beliefs and anxiety', International Journal in Educational Sciences 4(3), 261-270.
Mullis, I.V.S., Martin, M.O., Gonzalez, E., O'Connor, K.M., Chrostowski, S.J., Gregory, K.D., Garden, R.A. \& Smith, T.A., 2001, TIMSS 1999 benchmarking mathematics report, TIMSS \& PIRLS International Study Center, Boston College, Chestnut Hill, MA, viewed 02 October 2014, from http://timss.bc.edu/timss1999b/mathbench report/t99b_math_report.html

Mutodi, P. \& Ngirande, H., 2014, 'The influence of students' perceptions on mathematics performance. A case of a selected high school in South Africa', Mediterranean Journal of Social Sciences 5(3), 431-445.

Pandor, N., 2008, Address by the Minster of Education, Report on the Foundation Phase Conference Limpopo, September 30-October 1, 2008, viewed 6 September 2014, from http://www.unicef.org/southafrica/SAF_resources_fpcbrochures.pdf

Pather, S., 2012, 'Activity theory as a lens to examine pre-service teachers' perceptions of learning and teaching of mathematics within an intervention programme', African Journal of Research in Mathematics, Science and Technology Education 16(2), 253-267.

Peker, M., 2009, 'Pre-service teachers' teaching anxiety about mathematics and their learning styles', Eurasia Journal of Mathematics, Science \& Technology Education 5(4), 335-345.

Pepin, B., 2011, 'Pupils' attitudes towards mathematics: A comparative study of Norwegian and English secondary students' attitude toward mathematics', The International Journal on Mathematics Education 43, 535-546.

Pickens, J., 2005, 'Attitudes and perceptions', in N. Borkowski (ed.), Organizational behavior in health care, pp. 43-75, Jones and Bartlett Publishers, Sudbury.

Puteh, M., 2002, 'Qualitative research approach towards factors associated with mathematics anxiety', in P. Valero \& O. Skovsmose (eds.), Proceedings of the 3rd International Mathematics Education and Society Conference, pp. 1-5, Centre for Research in Learning Mathematics, Copenhagen.

Rayner, V., Pitsolantis, N. \& Osana, H., 2009, 'Mathematics anxiety in preservice teachers: Its relationship to their conceptual and procedural knowledge of fractions', Mathematics Education Research Journal 21(3), 60-85.

Richardson, F. \& Suinn, R., 1972, 'The mathematics anxiety rating scale: Psychometric data', Journal of Counseling Psychology 19(6), 551-554.

Schoenfeld, A.H., 1985, Mathematical problem-solving, Academic Press, New York.

Schoenfeld, A.H. (ed.), 1994, Mathematical thinking and problem solving, Erlbaum, Hillsdale.

Schunk, D. \& Meece, J.L., 1992, Student perceptions in the classroom, Lawrence Erlbaum Associates, Hillsdale.

Schunk, D.H., 1996, 'Self-efficacy for learning and performance', paper presented at the meeting of the American Educational Research Association, New York.

Strauss, A. \& Corbin, J., 2008, Basics of qualitative research: Grounded theory procedures and techniques, 3rd edn., Sage, Newbury Park.

Tapia, M. \& Marsh, G.E., 2004, 'An instrument to measure mathematics attitudes', Academic Exchange Quarterly 8(2), 2004.

Tchoshanov, M., Blake, S., Della-Pianna, C., Duval, A. \& Sanchez, S., 2001, 'Students' perceptions of cross-disciplinary team teaching on site at a professional development school', 53rd Annual Meeting \& exhibits, American Association of Colleges for Teacher Education, Dallas, TX, March 1-4, 2001.

The concise Oxford English dictionary, 2006, Oxford University Press, Oxford.

Uusimaki, L. \& Nason, R., 2004, 'Causes underlying pre-service teachers' negative beliefs and anxieties about mathematics', Proceedings of the 28th Conference of the International Group for the Psychology of Mathematics Education, vol. 4, pp. 369-376.

White, A.L., Way, J., Perry, B. \& Southwell, B., 2005-2006, 'Mathematical attitudes, beliefs and achievement in primary pre-service mathematics teacher education', Mathematics Teacher Education and Development 7, 33-52.

Yüksel-Sahin, F., 2008, 'Mathematics anxiety among 4th and 5th grade Turkish elementary school students', International Electronic Journal in Mathematics Education 3, 179-192.

Zakaria, E. \& Nordin, N.M., 2008, 'The effects of mathematics anxiety on matriculation students as related to motivation and achievement', Eurasia Journal of Mathematics, Science \& Technology Education 4(1), 27-30.

Zan, R. \& Di Martino, P., 2007, 'Attitude toward mathematics: Overcoming the positive/negative dichotomy', The Montana Mathematics Enthusiast, Monograph 3, 157-168.

Zimmerman, B.J., 2002, 'Becoming a self-regulated learner: An overview', Theory into Practice 41(2), 64-70. 